Max-Planck-Institut für demografische Forschung

Max Planck Institute for Demographic Research

Konrad-Zuse-Strasse 1 - D-18057 Rostock - GERMANY

Tel +49 (0) 3812081 - 0; Fax +49 (0) 3812081 - 202;

http://www.demogr.mpg.de

MPIDR WORKING PAPER WP 2011-011

JULY 2011 (REVISED SEPTEMBER 2011)

\title{
Child Schooling, Child Health and \\ Rainfall Shocks: \\ Evidence from Rural Vietnam
}

\author{
Thuan Q. Thai (thai@demogr.mpg.de) \\ Evangelos M. Falaris
}

This working paper has been approved for release by: Mikko Myrskylä (myrskyla@demogr.mpg.de), Head of the Max Planck Research Group on Lifecourse Dynamics and Demographic Change.

(C) Copyright is held by the authors.

Working papers of the Max Planck Institute for Demographic Research receive only limited review. Views or opinions expressed in working papers are attributable to the authors and do not necessarily reflect those of the Institute. 


\title{
Child Schooling, Child Health and Rainfall Shocks: Evidence from Rural Vietnam
}

\author{
by \\ Thuan Q. Thai * \\ and \\ Evangelos M. Falaris**
}

July 2011

*Thai: Max Planck Institute for Demographic Research, Konrad-Zuse-Strasse 1, 18057 Rostock, Germany; e-mail: thai @ demogr.mpg.de; telephone: + 49 (0)381 2081-236.

**Falaris: Department of Economics, University of Delaware, Newark, DE, 19716, USA; e-mail: falaris@udel.edu; telephone: +1-302-831-1768. We would like to thank Saul Hoffman, Mikko Myrskylä, Peter Schnabl, Simon Condliffe, James Mulligan, and the colleagues at the Max Planck Institute for Demographic Research for their comments, and the General Statistical Office of Vietnam for making the data available. 


\begin{abstract}
We study the effect of early life conditions, proxied by rainfall shocks, on schooling and height in rural Vietnam. Our measure of rainfall shock is defined as deviations from the long-run average. Many Vietnamese rural dwellers engage in rain-fed crop production, mostly irrigated paddy rice. Sufficient annual rainfall could play an important role in the harvest and thus, the household income. Nutritional deficiencies resulting from the household's income shocks may have negative consequences on health. We find that a negative rainfall shock during gestation delays school entry and slows progress through school. In addition, a negative rainfall shock in the third year of life affects adversely both schooling and height. The effects differ by region in ways that reflect differing constraints on families that are shaped by regional economic heterogeneity. We predict that policies that help rural families smooth income shocks will result in increases in human capital and in substantial cumulative returns in productivity over the life course.
\end{abstract}

Keywords: child health, z-score, school entry delay, schooling gap, rainfall shocks, Vietnam.

JEL classifications: I12, J24, J13, O15. 


\section{Introduction}

It is well documented that health and nutrition stress during gestation and a child's early years of life can have adverse effects on the child's full intellectual and physical development ${ }^{1}$ and can thus affect later life outcomes. Previous research has measured stress on a child by examining the effect of disease (Almond 1996; Bozzoli et al., 2009), weather (Maccini and Yang, 2009), disasters and war (Alderman et al. 2006, 2009; Hoddinott and Kinsey, 2001), or price shocks (Glewwe et al., 1995; Alderman et al., 2001) during gestation or a child's early years. The previous research has established using data from several countries that early life shocks are associated with long-lasting adverse later life outcomes. We contribute to the literature by studying the effect of rainfall shocks on two child schooling outcomes and on height-for-age (a measure of child health) in rural Vietnam. We find that adverse rainfall shocks during gestation adversely affect schooling outcomes. Adverse rainfall shocks in the third year of life adversely affect both schooling and our measure of child health. These effects differ by region in ways that reflect differing constraints on families that are shaped by regional economic heterogeneity.

We estimate reduced form equations and find that rainfall shocks during the period in utero affect children's school entry delay and progress through school. A more adverse rainfall shock, by which we mean a lower annual rainfall relative to the average (negative rainfall shock), during this period results in greater school entry delay and slower progress through the grades. Similar rainfall shocks in the third year of life also negatively affect these two schooling outcomes and in addition affect a child's height-for-

\footnotetext{
${ }^{1}$ Glewwe and Miguel (2008) and Strauss and Thomas (2008) survey many of the studies on the impact of early life health and nutrition.
} 
age. The evidence is consistent with an adverse weather shock affecting child health, which affects schooling outcomes. Some previous studies focused on later life effects of stress in utero (Barker, 1998; Almond, 2006). Other studies found adverse effects of stress in early childhood (e.g. Maccini and Yang, 2009; Glewwe et al., 2001). We find evidence that both stresses in utero and in the third year of life have later adverse consequences. In addition we test for regional differences in the effects of rainfall shocks within Vietnam. We find that in regions where there are relatively more farmers who find it difficult to smooth consumption over time in the face of an income shock, an adverse rainfall shock has bigger effects on children's health and schooling outcomes than in other regions. Our estimates are of empirically meaningful magnitude, suggesting that policies that help rural families smooth income shocks will have significant long run payoffs. We predict that such policies will result in increases in human capital and in substantial cumulative returns over a worker's working life.

\section{Methodology}

A possible conceptual underpinning of our empirical work could be a model such as that of Glewwe and Miguel (2008), according to which parents make choices on investment in their children's health and on investment in the children's human capital. Thus, child health and human capital outcome variables should be treated as jointly endogenous. According to this model, a healthier child is more ready to start school at the conventional age and make academic progress relative to a less healthy child. Child health has multiple dimensions which affect human capital investment and it is not feasible to estimate a structural model for these outcomes. 
In our empirical work we study two child human capital investment variables measuring years of school entry delay and progress through the grades while a child was in school (years of schooling gap). We also observe child height-for-age, a widely used measure of child health. In addition to various control variables we have measures of deviations of rainfall from its long term mean near the community where the child was born during the periods of a year before a child's birth and during the child's early childhood (rainfall shock variables). The rainfall shock variables can be treated as being outside the control of parents making decisions. An adverse rainfall shock such as a drought may reduce a family's farming income. If the family faces constraints that make it difficult to smooth consumption, a reduction in income following an adverse rainfall shock may lead to worse nutrition for their children. Worse nutrition may adversely affect child health which in turn has adverse effects on readiness to start school on time and progress through school. Children's health, however, has many dimensions (Strauss and Thomas, 1998) each of which may have a separate impact on the human capital investment measures we study. One is height-for-age a severe shortfall of which is called stunting. Others may include cognitive ability, immune system development, lung capacity and others. All these measures of health may be affected by an adverse rainfall shock but we only observe height-for-age. The measures of health other than height-forage are unobserved by us and would thus be part of the error term of a structural equation that has one of the human capital variables as the left-hand-side variable and height-forage as a right-hand-side variable. A measure of rainfall shock would not be a valid instrument for estimating such a structural equation because it would be correlated with cognitive ability, immune system development, lung capacity, etc. that are included in the 
error term. In this case rainfall shock is an external variable but is not exogenous in that equation (Deaton, 2010) and can not be used as an instrument.

Since we can not use rainfall shocks as an instrument, we adopt a reduced form approach similar to the empirical methodology of Maccini and Yang (2009). Our aim is to find out if rainfall shocks during gestation and in early childhood have an effect on the two human capital investment measures and on height-for-age. We do not try to uncover the complete structural path through which rainfall shocks affect these outcome variables but make inferences from reduced form equations. The coefficient of a measure of rainfall shock in a reduced form equation with a human capital outcome as the left-handside variable is a combination of structural coefficients that characterize how the rainfall shock is related to the health and the human capital outcome. We do not disentangle the structural coefficients.

We estimate three reduced form equations. These are for years of school entry delay, a measure of progress through the grades while enrolled (years of schooling gap) and standardized height-for-age. In each equation we allow for commune (local administrative unit) and birth year fixed effects. We control for parents' characteristics, and also for rainfall shock during the 12 months preceding a child's birth (we call it year in utero), rainfall shock during the birth year, rainfall shock during the first year following the birth year and rainfall shock during the second year following the birth year. We also include quadratic terms of all rainfall shock measures to allow for nonlinear effects. Our main interest resides in the effects of rainfall shocks in each of these periods on child health and human capital investment. 


\section{Data and Variables}

We use the 1998 Vietnam Living Standards Survey (VNLSS) and consider children age 6-19 living in rural areas with both parents. The VNLSS survey selects households for interview by selecting communes (the lowest local administrative unit in Vietnam) and then selecting randomly two villages in each commune from which households are selected. Households in Vietnam generally have similar socioeconomic characteristics by commune, therefore it is reasonable to cluster standard errors by commune in the estimation. Our sample includes information on children of households residing in 136 rural communes. These are located in seven regions of the country. The official definition of regions generally reflects differences in climate, topography and economic characteristics.

In our empirical work we examine the impact of early life rainfall shocks on two human capital outcome variables and on a measure of children's health. The first variable measure years of school entry delay, the second which we call schooling gap measures progress through school while a child was enrolled in school, and the health measure is height-for-age.

The minimum age for school entry age in Vietnam is six. There is a question in the survey on the age at which a child started school. We define years of school entry delay as the reported age at which a child started school entry minus six. For a small proportion of children ( 8.79 percent $)$ it is reported that the child started school earlier than at age six. It appears that these were children born right after the cutoff date who were allowed to enroll a year early. We retain these negative values (specifically -1) of years of entry delay in order to avoid introducing censoring bias in our regressions. 
The second human capital outcome that we study is years of schooling gap, which is defined as age when leaving school or current age minus highest grade completed minus six. Age when leaving school applies to children no longer enrolled in school as of the interview date. Current age applies to children that are enrolled as of the interview date. Years of schooling gap and years of entry delay are related: a child that completes a given number of grades and progresses through the grades without repeating any of them but starts school a year late has a schooling gap of one year. Repeating grades, skipping grades, or leaving school for a time and resuming attendance later introduces independent variation in the years of schooling gap. Thus it may be possible for a child to make up an entry delay or to fall further behind. A small proportion (4.5 percent) of children have a negative value (-1) of years of schooling gap. We retain these observations in order to avoid censoring bias. Given the relative youth of our sample, we would have severe right censoring if we tried to model an outcome variable of highest grade completed, therefore we have not attempted to do so.

We measure child health by means of the standardized height-for-age (or heightfor-age transformed into a z-score $)^{2}$. We measure a child's age in months for the purpose of calculating the height-for-age z-score. We wish to study a measure of the health stock of a child that may be relevant for school entry readiness and for making progress through school, and that may be affected by shocks experienced early in life in a manner that persists over time. The z-score of height-for-age may be a suitable measure in that

\footnotetext{
${ }^{2}$ We transform height-for-age into a z-score using the reference height-for-age distribution of children in the United States which is published by the National Center for Health Statistics. The z-score is a standardized indicator of health that is comparable across ages and genders. A child is considered stunted if his or her z-score is below -2. In our empirical work we assume that the child health stock that is most relevant for school entry readiness and school progress does not change considerably after age 6. Therefore, we use z-scores at the interview date when a child may be older than six to approximate the health stock at age 6 or while attending school.
} 
adverse early life shocks that adversely affect early life nutrition may result in a child being stunted. This condition may result in the child being less ready to start and to progress in school in a less timely manner than a similar child that does not experience the adverse shock. We contrast this measure from other measures of health such as a short-duration illness from which it may be possible to recover completely a short time later. In our framework, the effect of an early life shock would not necessarily be apparent in later short-duration illness.

As control variables we use parents' education levels measured by highest grade completed and parents' heights. Parents' education levels are likely to be particularly relevant in children's human capital investments: more educated parents are likely to attach greater value and to have more means to invest in the human capital of their children. Parents' heights are likely to be particularly relevant in affecting children's height-for-age since height has a genetic component. However, since we are estimating reduced forms, the appropriate procedure is to include all control variables (parents' schooling and height) in all equations. For our purposes we are assuming that these characteristics of the parents are given as of the time families are making health and human capital investment decisions for their children.

We use historical information on rainfall in Vietnam to construct measures of rainfall shocks during a child's years of early life. We use data on estimated precipitation developed by climate researchers (Legates and Willmott, 1990). ${ }^{3}$ Rainfall data come from the Gridded Monthly Time Series (Version 2.01) dataset, henceforth, GMTS. This dataset contains global historical estimates of rainfall for a grid of 0.5 degree by 0.5 degree of

\footnotetext{
${ }^{3}$ The dataset is provided by Center for Climatic Research, Department of Geography, University of Delaware. Terrestrial Precipitation: 1900-2008 Gridded Monthly Time Series - Version 2.01, interpolated and documented by Kenji Matsuura and Cort J. Willmott (with support from IGES and NASA).
} 
latitude/longitude, where the grid nodes are centered on 0.25 degree. Thus, the area covered by each grid is approximately 50 square kilometers. This is also the maximum distance between a commune and its closest grid point of rainfall. To derive measures of rainfall shocks, we match each commune in the VLSS sample with the four closest grid points in the GMTS dataset. Since there was no information on longitude and latitude for each commune in the version of the VLSS available to us, we determine its geographical location using the administrative map of the Government of Vietnam. ${ }^{4}$ We use average rainfall over the four grid points, which surround the location of the child's commune, as our measure of commune-specific rainfall. ${ }^{5}$ We calculate the average of annual rainfall for each commune over the 48-year period from 1950 to 1998 . Finally, we define the rainfall shock for a specified interval as the percentage change of the total 12 month rainfall in the specified interval such as the 12 months following a child's birth, 1 year after birth year etc. over the average of annual rainfall in the child's commune. ${ }^{6}$ The 12 month interval preceding the date of birth includes the period of gestation when a fetus may be vulnerable to adverse shocks that affect the mother. It also includes a few months before the period of gestation started. It is possible that rainfall shocks at a point in time

\footnotetext{
${ }^{4}$ Further details are available at http://gis.chinhphu.vn/. The map for sample communes and closest grid points is available from the authors on request.

${ }^{5}$ Using estimated precipitation data and averaging the values of the four grid points is likely to mitigate the effect of possible measurement error in measured precipitation data which are the starting point of the GMTS. Zimmermann (2011) used GMTS data for India developed by the same researchers and investigated whether or not using instrumental variables to control for possible measurement error significantly affected the estimates. Zimmermann found no significant effects on her estimates of controlling for measurement error in the rainfall data.

${ }^{6}$ This rainfall shock is therefore equal to the difference in the logarithms of rainfall in a specified interval and mean annual rainfall. Our definition of rainfall shock is related to that in Maccini and Yang (2009). However, the time interval they consider is the twelve months for the two consecutive wet and dry seasons, starting with the season in which a child is born (their birth year shock) and the intervals preceding or following. Our definition is more closely related to the early life cycle of the child. Theirs can cover rainfall in some months before the child's birth for some children but not for others, thus a different span of each child's early life cycle.
} 
have lagged effects on income and nutrition. For this reason we define all rainfall shocks to encompass equal intervals.

The edited sample consists of 4735 observations (schooling gap and standardized height-for-age equation) and 4608 observations (years of entry delay equation). Variable definitions appear in Table 1 and summary statistics are in Table 2. We dropped observations because of missing values or because some families had migrated. We

Table 1. Variable Definitions

\begin{tabular}{|c|c|}
\hline \multicolumn{2}{|l|}{ Variables } \\
\hline Male ( 1 if male) & 1 if male \\
\hline ethnicity & 1 if Kinh, the majority ethnic group \\
\hline Years of entry delay & $=($ reported age at school entry -6$)$ \\
\hline Years of schooling gap & $\begin{array}{l}=\text { [reported age when leaving school (if not in school) or } \\
\text { current age (if in school) - highest number of grades } \\
\text { completed - 6] }\end{array}$ \\
\hline height for age z-score & $\begin{array}{l}\text { height for age (in months) relative to the US population as of } \\
\text { the interview date }\end{array}$ \\
\hline father's education & years completed \\
\hline mother's education & years completed \\
\hline father's height & in centimeters \\
\hline mother's height & in centimeters \\
\hline Rainfall shock in: & $\begin{array}{l}\text { difference in the logarithms of rainfall in commune of birth } \\
\text { during a specified interval and mean annual rainfall (1950- } \\
\text { 1998) in that commune }\end{array}$ \\
\hline year in utero & 12 months preceding birth \\
\hline Birth year & 12 months following birth \\
\hline 1 st year after birth year & the second year of the child's life \\
\hline 2nd year after birth year & the third year of the child's life \\
\hline $\mathrm{RM}$ regions & Red River Delta and Mekong River Delta \\
\hline
\end{tabular}

omitted observations on 151 children, 10 years of age or more, for whom information on all other variables is available, because the child was born in a different place than the commune of residence as of the interview date. The province but not the commune of 
birth of these children is reported. Communes are subsets of provinces. We can not match these children accurately to the grid coordinates. In order to avoid error in associating these observations with local (commune) rainfall data, it is simpler to omit them. Obviously, the reduction in sample size is modest.

Table 2. Summary statistics

\begin{tabular}{lrrrrr}
\hline Variables & Mean & Std. & Min & Max & N \\
\hline & & & & & \\
age & 11.83 & 3.71 & 6 & 19 & 4735 \\
male & 0.52 & 0.50 & 0 & 1 & 4735 \\
ethnicity (1 if Kinh) & 0.87 & 0.34 & 0 & 1 & 4735 \\
years of entry delay & 0.31 & 0.86 & -1 & 5 & 4608 \\
years of schooling gap & 0.93 & 1.18 & -1 & 7 & 4735 \\
height for age zscore & -1.98 & 0.92 & -4.98 & 2.52 & 4735 \\
father's education & 7.57 & 3.01 & 1 & 19 & 4735 \\
mother's education & 6.49 & 3.04 & 1 & 16 & 4735 \\
father's height & 162.09 & 5.47 & 142.40 & 182.00 & 4735 \\
mother's height & 151.98 & 4.81 & 132.10 & 177.50 & 4735 \\
Rainfall shock in: & & & & & \\
year in utero & -0.21 & 0.33 & -2.02 & 0.42 & 4735 \\
birth year & -0.26 & 0.33 & -2.02 & 0.41 & 4735 \\
1st year after birth year & -0.30 & 0.34 & -1.90 & 0.60 & 4735 \\
2nd year after birth year & -0.30 & 0.34 & -2.02 & 0.60 & 4735 \\
\hline
\end{tabular}

As we report in Table 2, the mean duration of school entry delay is approximately one third of a year and the mean duration of the schooling gap is greater at 0.93 of a year. Grade repetition and interruptions of children's schooling are significant phenomena. The standardized height-for-age for the children in our sample is 1.98 standard deviations below the median of the reference height-for-age distribution. Forty-nine percent of children are stunted since their standardized z-score is less than -2 . This is a higher rate 
of stunting than the rate of 35 percent reported in Glewwe (2004) for children aged 0-60 months using the same data. In our sample older children faced difficult conditions relative to younger children.

Another noteworthy feature of the data is that the average rainfall shock is negative indicating drought conditions (precipitation less than mean precipitation in the location by 21-30 percent depending on the period). This low rainfall is linked to the fact that Vietnam is one of the countries influenced by the recurrent impact of the El Niño Southern Oscillation (ENSO) climate phenomenon. An ENSO happens every 2 to 7 years and is typically associated with anomalies in precipitation resulting in severe drought in the case of Vietnam (United Nations, 2000). In our sample, which includes individuals born between 1978 and 1992, three strong episodes of ENSO were recorded in the years 1982-83, 1986-87 and 1991-92 (Trenberth, 1997). The low rainfall level during these episodes was not offset by sufficient high rainfall episodes in the sample period. Therefore, we consider the negative values of the mean early life rainfall shocks ${ }^{7}$ to be plausible.

\section{Estimates}

\section{a. The Effects of Rainfall Shocks}

We report estimates of the reduced form outcome equations for years of entry delay, years of schooling gap and the standardized height-for-age in Table 3. The coefficients of rainfall shocks during the year in utero are negative and significant in both

\footnotetext{
${ }^{7}$ It should be noted that the Indonesian sample used in Maccini and Yang (2009) covers a longer range of birth cohorts (1953-1974) and without unusually pronounced drought episodes. Their sample average rainfall shock is therefore closer to zero.
} 
the years of entry delay and years of schooling gap equations ${ }^{8}$. A positive rainfall shock results in a shorter entry delay and faster progress through school while a negative rainfall shock has the opposite effects. A rainfall shock also affects years of schooling gap nonlinearly in a way that, at the margin, reinforces the main effect of a positive rainfall shock but moderates the effect of a negative rainfall shock. The coefficient of the years of schooling gap equation is more negative than that of the years of entry delay equation, therefore more rain reduces grade repetition and intervals of non-attendance in addition to reducing entry delay. We note that a rainfall shock during the year in utero does not have a significant effect on standardized height-for-age. It is possible that rainfall affects family income which may affect the quality of nutrition or medical care received by the mother at a crucial stage of gestation. This in turn would affect the cognitive development of the child, which influences the child's human capital outcomes. So a rainfall shock during the period in utero does not significantly affect the standardized height-for-age but may affect another aspect of child development for which we do not have a measure.

We estimate negative and significant coefficients for rainfall shocks in the second year after the birth year (the third year of life) in both the years of entry delay and years of schooling gap equations. The coefficient in the years of schooling gap equation is more negative indicating that a favorable rainfall shock affects not only years of entry delay but also improves progress through the grades. A rainfall shock in the second year after the birth year has a positive coefficient in the standardized height-for-age equation. More rainfall results in better child health which is expressed in higher standardized

\footnotetext{
${ }^{8}$ The former at the 10 percent level, the latter at the 5 percent level.
} 
Table 3. Estimates of the Reduced Form Outcome Equations

\begin{tabular}{|c|c|c|c|}
\hline Variables & $\begin{array}{c}\text { Years of entry } \\
\text { delay }\end{array}$ & $\begin{array}{c}\text { Years of schooling } \\
\text { gap }\end{array}$ & $\begin{array}{l}\text { Standardized height- } \\
\text { for-age }\end{array}$ \\
\hline male & $\begin{array}{l}0.041 \\
(0.02)\end{array}$ & $\begin{array}{c}0.184 * * \\
(0.03)\end{array}$ & $\begin{array}{c}-0.173 * * \\
(0.02)\end{array}$ \\
\hline ethnicity ( 1 if Kinh) & $\begin{array}{c}-0.170+ \\
(0.09)\end{array}$ & $\begin{array}{c}-0.241+ \\
(0.12)\end{array}$ & $\begin{array}{r}-0.005 \\
(0.08)\end{array}$ \\
\hline father's education & $\begin{array}{c}-0.028 * * \\
(0.01)\end{array}$ & $\begin{array}{c}-0.034 * * \\
(0.01)\end{array}$ & $\begin{array}{l}0.007 \\
(0.01)\end{array}$ \\
\hline mother's education & $\begin{array}{c}-0.031 * * \\
(0.01)\end{array}$ & $\begin{array}{c}-0.048 * * \\
(0.01)\end{array}$ & $\begin{array}{l}-0.002 \\
(0.01)\end{array}$ \\
\hline father's height & $\begin{array}{c}-0.005^{*} \\
(0.00)\end{array}$ & $\begin{array}{c}-0.008^{*} \\
(0.00)\end{array}$ & $\begin{array}{c}0.040 * * \\
(0.00)\end{array}$ \\
\hline mother's height & $\begin{array}{l}-0.000 \\
(0.00)\end{array}$ & $\begin{array}{l}-0.006 \\
(0.00)\end{array}$ & $\begin{array}{c}0.048 * * \\
(0.00)\end{array}$ \\
\hline \multicolumn{4}{|l|}{$\begin{array}{l}\text { Coefficients for rainfall } \\
\text { shocks in: }\end{array}$} \\
\hline year in utero & $\begin{array}{l}-0.170+ \\
(0.09)\end{array}$ & $\begin{array}{c}-0.304 * * \\
(0.11)\end{array}$ & $\begin{array}{l}0.006 \\
(0.10)\end{array}$ \\
\hline year in utero squared & $\begin{array}{l}-0.111 \\
(0.08)\end{array}$ & $\begin{array}{l}-0.179+ \\
(0.10)\end{array}$ & $\begin{array}{l}0.057 \\
(0.09)\end{array}$ \\
\hline birth year & $\begin{array}{l}-0.117 \\
(0.10)\end{array}$ & $\begin{array}{l}0.169 \\
(0.15)\end{array}$ & $\begin{array}{l}-0.137 \\
(0.11)\end{array}$ \\
\hline birth year squared & $\begin{array}{l}-0.077 \\
(0.09)\end{array}$ & $\begin{array}{l}0.134 \\
(0.13)\end{array}$ & $\begin{array}{l}-0.001 \\
(0.08)\end{array}$ \\
\hline 1st year after birth year & $\begin{array}{l}0.039 \\
(0.11)\end{array}$ & $\begin{array}{l}0.088 \\
(0.13)\end{array}$ & $\begin{array}{l}0.076 \\
(0.10)\end{array}$ \\
\hline 1 st year squared & $\begin{array}{l}0.063 \\
(0.10)\end{array}$ & $\begin{array}{l}0.123 \\
(0.14)\end{array}$ & $\begin{array}{l}0.045 \\
(0.10)\end{array}$ \\
\hline 2nd year after birth year & $\begin{array}{c}-0.272 * * \\
(0.10)\end{array}$ & $\begin{array}{c}-0.392 * * \\
(0.12)\end{array}$ & $\begin{array}{l}0.244^{*} \\
(0.09)\end{array}$ \\
\hline 2nd year squared for Mekong & $\begin{array}{r}-0.069 \\
(0.09)\end{array}$ & $\begin{array}{l}-0.142 \\
(0.13)\end{array}$ & $\begin{array}{c}0.192 * * \\
(0.07)\end{array}$ \\
\hline $\begin{array}{l}\text { 2nd year squared for other } \\
\text { regions }\end{array}$ & $\begin{array}{l}-0.214^{*} \\
(0.10)\end{array}$ & $\begin{array}{l}-0.316^{*} \\
(0.12)\end{array}$ & $\begin{array}{l}0.166 \\
(0.12)\end{array}$ \\
\hline R-squared & 0.14 & 0.17 & 0.19 \\
\hline $\mathrm{N}$ & 4608 & 4735 & 4735 \\
\hline
\end{tabular}

Fixed effects for commune, birth year and an overall intercept are also included. Standard errors are in parentheses. The estimates of the standard errors take account of the clustering of observations by commune.

$+\mathrm{p}<0.10,{ }^{*} \mathrm{p}<0.05,{ }^{*} \mathrm{p}<0.01$ 
height-for-age. Our estimates are consistent with more rainfall resulting in higher family income, which leads to better nutrition, and consequently improves child health and schooling outcomes. The third year of life is a time when a child has been weaned but whose development is still vulnerable to an adverse nutrition shock (Glewwe and Miguel, 2008) that the family may be unable to offset.

Maccini and Yang (2009) documented a similar pattern for Indonesia for rainfall only during the birth year but not during the year in utero or the third year of life. As discussed above, our measure of rainfall shocks is more closely associated with the early life cycle of a child than theirs is and we are also using data from a different country in comparison with theirs.

In the standardized height-for-age equation we initially estimated a common coefficient for quadratic rainfall shock for the entire country and obtained a positive and significant coefficient. A positive quadratic rainfall shock coefficient means that more rain reinforces the positive main effect of a rainfall shock but a drought eventually offsets the main rainfall shock effect as it gets more severe. In other words more rain is good but a severe drought may also be helpful. There is a plausible interpretation of this pattern in one region: the Mekong Delta.

In the Mekong delta more rain helps increase rice yields but drought results in increased water salinity which is helpful in aquaculture such as shrimp farming (Sumernet, 2011). In other words rain helps one important farm activity but drought helps another activity. A similar pattern is likely to be less relevant elsewhere in Vietnam. Therefore, we allow the effect of quadratic rainfall shock to be different for the Mekong Delta than for other regions. The resulting estimates are of a positive and 
significant coefficient for Mekong (rice or aquaculture effects) but of an insignificant coefficient for other regions in the standardized height-for-age equation. For the schooling outcome equations we estimate negative quadratic rainfall shock coefficients. These reinforce, at the margin, the effects of an increase in rainfall and moderate the effects of a decrease for regions other than the Mekong Delta.

The remaining coefficient estimates indicate that boys are at a disadvantage relative to girls in the standardized height-for-age equation and also in the years of schooling gap equation. We find no significant difference by gender in the years of entry delay equation. Members of the ethnic majority group experience more favorable schooling outcomes. Parents' schooling levels affect favorably a child's schooling outcomes but have no significant effect on standardized height-for-age. Parents' heights positively affect a child's height, as one would expect, but only father's height favorably affects the child's schooling outcomes. A plausible sequence of events that is consistent with our reduced form estimates is that father's height may indicate good health which is positively correlated with earning capacity. Higher father's earning capacity, in turn, is likely to result in improved schooling outcomes for a child.

The implication of these findings is that policies that protect mother's nutrition during gestation will be beneficial to children by making it more likely they will start school on time and make timely progress through school. Another implication is that protecting child nutrition in the vulnerable period after weaning, the third year of life, will reduce the incidence of stunting, allow children timely school entry and progress through school. These policies are likely to result in more productive future workers. 


\section{b. Regional Effects}

Having established that rainfall shocks in utero and during the third year of life have effects on the three schooling and health outcomes, we now investigate further the role of regional effects of rainfall shocks during early life. There is considerable regional variation in the types of crops and productive activities across rural Vietnam. Institutional constraints that were in effect during the relevant time period also made it relatively harder for many families in some regions to smooth consumption in the face of income shocks relative to families in other regions. We expect that the effects of rainfall shocks during a child's early life will be relatively bigger for these families that found it relatively more difficult to smooth consumption.

Ideally, we would expand the reduced form models reported in Table 3 to allow for separate effects of each rainfall shock variable (and its quadratic term) for each of the seven regions of Vietnam. The number of parameters that we would have to estimate is large and precision falls considerably. Instead, we allow for a regional dimension in the rainfall shock variables that we found to have significant effects on the outcomes: the year in utero and the second year after the birth year (third year of life). We also allow for two separate regional effects on the basis of the importance of small farms that produce rice. Thus we allow for separate effects of rainfall shocks during the year in utero and the second year after the birth year for the Red River Delta and Mekong Delta (RM) regions and for all other regions. We report estimates of the reduced forms with regional effects in Table 4. Statistical tests confirm that the rainfall shock coefficients are significantly different in RM compared to other regions., ${ }^{9,10}$

\footnotetext{
${ }^{9}$ We have $\mathrm{F}(2,134)=4.02$, Pr. $=0.02$ for years of entry delay; $F(2,134)=3.11$, Pr. $=0.048$ for years of schooling gap and $\mathrm{F}(2,134)=3.64$, Pr. $=0.029$ for standardized height-for-age.
} 
Before discussing the estimates of the models with regional effects, some information on the regional variation of economic activity in rural Vietnam during the relevant time period is helpful. The children in our sample were born in 1978-1992. Farmland in Vietnam was collectivized until 1988. During the 1980s rice production leveled off at the subsistence level (Dollar and Litvack, 1998). Rice is an important crop in several regions of Vietnam, particularly the Mekong and Red River Deltas. Its yield is relatively sensitive to rainfall. In that era of a command farm economy, adverse rainfall shocks caused production declines and hardship that farmers could not avoid.

Collectivization was reversed in 1988 and farmers were allocated land use rights. These rights could not be officially transferred or mortgaged until the Land Law of 1993 was implemented. In the transitional period of 1988-1992 small farms could not officially be consolidated. The banking system did not extend much credit to small poorer farmers prior to the establishment of a subsidized arm of the Agricultural Bank of Vietnam in 1995 (Wiens, 1998, Ravallion and Van de Walle, 2008). Small poorer farmers, in other words did not have access to credit through the banking system during the relevant period and found it difficult to exit agriculture or acquire more land. For these farmers, obtaining credit from moneylenders was costly and suppliers mostly extended credit to larger commercial growers of industrial or cash crops who would more reliably be able to repay a loan.

In this transitional period of 1988-1992 the Mekong Delta and Red River Delta regions (RM) had relatively many small poorer rice farmers. In the Mekong Delta

\footnotetext{
${ }^{10}$ Adding the North Central region (NC), which is the third highest region in Vietnam in terms of per capita rice production after the Mekong Delta and Red River Delta, to RM resulted in no significant difference in the RMNC-specific rainfall shock coefficients relative to rainfall shock coefficients for the rest of the regions.
} 
poorer farmers tended to have relatively low access to land. In the Red River Delta, average farm size was smaller than in the Mekong Delta. In addition water availability in the winter constrained rice output. In general, small farms tended to have lower total factor productivity than larger farms (Wiens, 1998). Rice tends to be cultivated on land that does not lend itself to crop diversification as easily as other land. Small poorer rice farmers would have difficulty acquiring and maintaining livestock that may provide an income buffer for less poor rice farmers. In other words, the RM region had many small and poorer rice farmers, whose crop and income were relatively sensitive to adverse rainfall shocks. These farmers had no access to credit and limited ability to diversify production, both mechanisms which could be used to smooth the effects of income shocks on consumption.

Farmers in other regions of Vietnam faced production conditions that resulted in the cultivation of a variety of crops, including industrial crops such as coffee or rubber, or of food crops such as cassava or beans, many of which may be relatively less sensitive to rainfall variation ${ }^{11}$ than is the production of rice. In one region, the Southeast, which was relatively more industrialized there were also available off farm work opportunities that could provide a buffer to rainfall fluctuations.

A rural family could mitigate the effect of an adverse rainfall shock by moving to a more favorable location. However, Vietnam had strict controls on geographic mobility until the early 1990s (Wiens, 1998). Thus a rural family could not readily respond to an adverse rainfall shock by moving.

\footnotetext{
${ }^{11}$ For example, planting coffee trees under taller shade trees may lessen the impact of a drought on the coffee trees (ASEAN Coffee, 2008).
} 
These arguments lead us to expect bigger effects of an adverse rainfall shock in RM than in the rest of rural Vietnam and this is what we find according to the estimates in Table 4. We report predictions on the effects of rainfall shocks in the next section. In particular, according to our estimates an adverse rainfall shock during the year in utero increases the years of schooling gap in RM more than twice as much as in other regions. The years of schooling gap change nonlinearly with a rainfall shock. The nonlinear effect reinforces, at the margin, the effect of an increase in rainfall and moderates the effect of a decrease. We find no significant effects of a rainfall shock during that year on the other outcomes. As with the estimates for the entire country, it appears that such a rainfall shock affects a child's cognitive development but does not have a significant effect on standardized height-for-age.

In the second year following the birth year (third year of life) an adverse rainfall shock results in more years of school entry delay, more years of schooling gap and higher standardized heath-for-age in RM. For RM the coefficient in the years of schooling gap equation is more negative than the coefficient in the years of entry delay equation. The implication is that an adverse rainfall shock results in school interruptions or grade repetion beyond the increase in entry delay. For the other regions only the effects of a rainfall shock on years of schooling gap and standardized height-for-age are significant and smaller than is the case for RM. We also estimate a positive quadratic rainfall shock coefficient for Mekong (more rainfall helps rice yields, drought is helpful to aquaculture) and negative quadratic rainfall coefficients for other regions in the schooling outcome 
Table 4. Estimates of the Reduced Form Outcome Equations with Regional Effects

\begin{tabular}{|c|c|c|c|}
\hline Variables & $\begin{array}{c}\text { Years of entry } \\
\text { delay }\end{array}$ & $\begin{array}{c}\text { Years of } \\
\text { schooling gap }\end{array}$ & $\begin{array}{l}\text { Standardized } \\
\text { height-for-age }\end{array}$ \\
\hline male & $\begin{array}{l}0.040 \\
(0.03)\end{array}$ & $\begin{array}{c}0.181 * * \\
(0.03)\end{array}$ & $\begin{array}{c}-0.171 * * \\
(0.02)\end{array}$ \\
\hline ethnicity (1 if Kinh) & $\begin{array}{c}-0.171+ \\
(0.09)\end{array}$ & $\begin{array}{c}-0.242+ \\
(0.12)\end{array}$ & $\begin{array}{r}-0.004 \\
(0.08)\end{array}$ \\
\hline father's education & $\begin{array}{c}-0.028 * * \\
(0.01)\end{array}$ & $\begin{array}{c}-0.033 * * \\
(0.01)\end{array}$ & $\begin{array}{l}0.007 \\
(0.01)\end{array}$ \\
\hline mother's education & $\begin{array}{c}-0.031 * * \\
(0.01)\end{array}$ & $\begin{array}{c}-0.048 * * \\
(0.01)\end{array}$ & $\begin{array}{r}-0.002 \\
(0.01)\end{array}$ \\
\hline father's height & $\begin{array}{c}-0.005+ \\
(0.00)\end{array}$ & $\begin{array}{c}-0.008^{*} \\
(0.00)\end{array}$ & $\begin{array}{c}0.040 * * \\
(0.00)\end{array}$ \\
\hline mother's height & $\begin{array}{l}0.000 \\
(0.00)\end{array}$ & $\begin{array}{l}-0.006 \\
(0.00)\end{array}$ & $\begin{array}{c}0.047 * * \\
(0.00)\end{array}$ \\
\hline Coefficients for rainfall shocks in: & & & \\
\hline year in utero, $\mathrm{RM}$ regions & $\begin{array}{l}-0.187 \\
(0.14)\end{array}$ & $\begin{array}{c}-0.510 * * \\
(0.15)\end{array}$ & $\begin{array}{l}0.153 \\
(0.13)\end{array}$ \\
\hline year in utero, other regions & $\begin{array}{l}-0.143 \\
(0.09)\end{array}$ & $\begin{array}{l}-0.217+ \\
(0.12)\end{array}$ & $\begin{array}{l}-0.053 \\
(0.11)\end{array}$ \\
\hline year in utero squared & $\begin{array}{l}-0.121 \\
(0.09)\end{array}$ & $\begin{array}{c}-0.281^{*} \\
(0.11)\end{array}$ & $\begin{array}{l}0.130 \\
(0.10)\end{array}$ \\
\hline birth year & $\begin{array}{l}-0.120 \\
(0.10)\end{array}$ & $\begin{array}{l}0.164 \\
(0.15)\end{array}$ & $\begin{array}{l}-0.135 \\
(0.11)\end{array}$ \\
\hline birth year squared & $\begin{array}{l}-0.081 \\
(0.09)\end{array}$ & $\begin{array}{l}0.115 \\
(0.13)\end{array}$ & $\begin{array}{l}0.012 \\
(0.08)\end{array}$ \\
\hline 1 st year after birth year & $\begin{array}{l}0.042 \\
(0.11)\end{array}$ & $\begin{array}{l}0.071 \\
(0.13)\end{array}$ & $\begin{array}{l}0.089 \\
(0.10)\end{array}$ \\
\hline 1 st year squared & $\begin{array}{l}0.057 \\
(0.10)\end{array}$ & $\begin{array}{l}0.102 \\
(0.14)\end{array}$ & $\begin{array}{l}0.059 \\
(0.10)\end{array}$ \\
\hline $\begin{array}{l}\text { 2nd year after birth year, RM } \\
\text { regions }\end{array}$ & $\begin{array}{c}-0.408 * * \\
(0.11)\end{array}$ & $\begin{array}{c}-0.493 * * \\
(0.12)\end{array}$ & $\begin{array}{c}0.290 * * \\
(0.11)\end{array}$ \\
\hline $\begin{array}{l}\text { 2nd year after birth year, other } \\
\text { regions }\end{array}$ & $\begin{array}{r}-0.169 \\
(0.11)\end{array}$ & $\begin{array}{c}-0.331^{*} \\
(0.13)\end{array}$ & $\begin{array}{l}0.220 * \\
(0.10)\end{array}$ \\
\hline 2nd year squared for Mekong & $\begin{array}{l}-0.148 \\
(0.10)\end{array}$ & $\begin{array}{l}-0.168 \\
(0.13)\end{array}$ & $\begin{array}{l}0.195^{*} \\
(0.08)\end{array}$ \\
\hline 2nd year squared for other regions & $\begin{array}{c}-0.179+ \\
(0.10)\end{array}$ & $\begin{array}{c}-0.328 * * \\
(0.12)\end{array}$ & $\begin{array}{l}0.182 \\
(0.12)\end{array}$ \\
\hline $\begin{array}{l}\text { R-squared } \\
\mathrm{N}\end{array}$ & $\begin{array}{l}0.14 \\
4608\end{array}$ & $\begin{array}{l}0.18 \\
4735\end{array}$ & $\begin{array}{l}0.19 \\
4735\end{array}$ \\
\hline
\end{tabular}

Fixed effects for commune, birth year and an overall intercept are also included. Standard errors are in parentheses. The estimates of the standard errors take account of the clustering of observations by commune.

$+\mathrm{p}<0.10,{ }^{*} \mathrm{p}<0.05, * * \mathrm{p}<0.01$ 
equations. At the margin, this nonlinear effect reinforces the effect of an increase in rainfall and moderates the effect of a decrease.

The importance of our regional findings is to show that credit constraints have adverse long run effects. Making it easier for credit-constrained farmers to smooth the effects on consumption of fluctuations in their income will have beneficial long run effects on their children. The findings also indicate that differentiating the effect of rainfall between regions in which rice is a particularly important crop and other regions reinforces the relevance of using rainfall shocks in our analysis.

\section{Predictions}

To show the implications of our estimates we present some predictions based on our preferred specification with regional effects whose estimates are in Table 4. We report changes in the predicted means both in years of entry delay, years of schooling gap and standardized height-for-age in response to changes in rainfall shocks assuming all else is held constant. We consider two hypothetical rainfall shocks: from zero to +0.30 and from zero to -0.30 . We note that approximately 0.30 is the standard deviation of the rainfall shocks in the data and the mean value of the rainfall shock is -0.21 to -0.30 . Put another way, a -0.3 to 0 rainfall shock is a return to long term normal rainfall. Our predictions are for the year in utero and for the second year after the birth year. We report the predictions in Table 5.

In scenario A (change from normal to plentiful rain) we predict that a favorable rainfall shock during the year in utero decreases years of schooling gap almost twice 
more in regions RM than in other regions. A similar change in rainfall during the second year after the birth year increases the standardized height-for-age more in the regions RM

Table 5. Predictions of the Effects of Rainfall Shocks

A. Rainfall shock 0 to $+\mathbf{0 . 3 0}$

\begin{tabular}{llccc}
\hline Period & Region & $\begin{array}{c}\text { Years of Entry } \\
\text { Delay }\end{array}$ & $\begin{array}{c}\text { Years of } \\
\text { Schooling Gap }\end{array}$ & $\begin{array}{c}\text { Standardized } \\
\text { height-for-age } \\
(\mathrm{cm})\end{array}$ \\
\hline \multirow{2}{*}{ year in utero } & RM & & -0.178 & \\
& Other Regions & & -0.090 & \\
\cline { 2 - 5 } 2nd year after & Mekong Delta & -0.122 & -0.148 & 0.105 \\
birth year & Red River Delta & -0.139 & -0.178 & $(0.48)$ \\
& Other Regions & -0.016 & -0.129 & 0.087 \\
& & & & 0.060 \\
& & & & $(0.28)$
\end{tabular}

B. Rainfall shock 0 to $-\mathbf{- 0 . 3 0}$

\begin{tabular}{llccc}
\hline Period & Region & $\begin{array}{c}\text { Years of Entry } \\
\text { Delay }\end{array}$ & $\begin{array}{c}\text { Years of } \\
\text { Schooling Gap }\end{array}$ & $\begin{array}{c}\text { Standardized } \\
\text { height-for-age } \\
(\mathrm{cm})\end{array}$ \\
\hline \multirow{2}{*}{ year in utero } & RM & & 0.128 & \\
& Other Regions & & 0.040 & \\
\cline { 2 - 5 } 2nd year after & Mekong Delta & 0.122 & 0.148 & -0.069 \\
birth year & Red River Delta & 0.106 & 0.118 & $\begin{array}{c}-0.32) \\
-0.087\end{array}$ \\
& Other Regions & -0.016 & 0.070 & $-0.40)$ \\
& & & & -0.060 \\
& & & & \\
& & & & \\
\end{tabular}

The predictions are based on rainfall shock coefficients in Table 4 that are significantly different from zero at the 10 percent level or better.

than in other regions. Also in regions RM, the increase in rainfall is predicted to decrease years of entry delay and years of schooling gap more than in other regions.

In scenario B (change from normal rainfall to drought; the latter condition being actually observed in the data) the predictions are not symmetric to scenario $\mathrm{A}$ in the cases where there are significant nonlinearities. Here we predict during the year in utero a 
bigger increase in years of schooling gap in RM than in other regions. For the second year after the birth year we predict a bigger decrease in standardized height-for-age in the Mekong Delta and especially in the Red River Delta than in other regions. Similarly we predict bigger increases in years of entry delay and years of schooling gap in regions $\mathrm{R}$ and $\mathrm{M}$ than in other regions.

Some of the differences across regions are sizable. For example the change in years of schooling gap ( $2^{\text {nd }}$ year after birth year) is more than twice as big for the Mekong Delta as for regions other than RM. The corresponding effect for Red River Delta is 69 percent bigger than the effect for regions other than RM. For the same period and scenario $\mathrm{B}$, the change in rainfall has an effect on standardized height-for-age that is 30 percent bigger for (the average of) RM than for other regions. For the year in utero the change in rainfall has an effect on years of schooling gap that is more than 3 times bigger for RM than for other regions. The reverse of scenario B in Table 5 is, approximately, a return of observed rainfall during the relevant period to long run normal rainfall. In terms of policy, a program that safeguards the nutrition of children during critical periods of the life cycle or a policy that helps families smooth consumption in the face of an income shock can have equivalent effects to the reverse of scenario B. Suppose such a policy is implemented in the third year of life. We predict that the policy will increase the standardized height-for-age of an average child, who lives in the Mekong Delta, Red River Delta and other regions by $0.07,0.09$ and 0.06 standard deviation, respectively. In terms of attained height, these are equivalent to an increase in height-for- age by 0.32 , 0.40 and 0.28 centimeters, respectively ${ }^{12}$. We also predict that this policy intervention

\footnotetext{
${ }^{12}$ We multiply the z-scores by 4.6 in order to convert them to centimeters. 4.6 centimeters is one standard deviation of height at age 5 .
} 
will decrease the years of schooling gap by 0.148 of a year in the Mekong Delta, by 0.118 in Red River Delta and by 0.07 of a year elsewhere. These predicted decreases of years of schooling gap are approximately 16 percent, 13 percent, and 8 percent of the sample mean. The estimated private annual rate of return to schooling in Vietnam has been estimated to be 4.8 percent (The World Bank, 1996). The decreases in years of schooling gap, then, imply annual returns of 0.71 percent for the Mekong Delta, 0.57 percent for the red River Delta and 0.34 percent for other regions. Over a worker's entire working life, these annual rates of return imply substantial cumulative returns.

\section{Conclusion}

We document that rainfall shocks in the year in utero and the second year after the year of birth in rural Vietnam affect children's human capital investments and health. Our findings are consistent with the findings of prior research on the role of adverse early life shocks in later life social and economic outcomes. The effects are bigger in regions where families find it relatively more difficult to smooth consumption when faced with an adverse income shock. We predict that policies aimed at safeguarding children's nutrition or policies that help families smooth consumption when faced with adverse income shocks during gestation or the post weaning period will have meaningful impacts. Public policy interventions in these particular periods of children's early life are therefore justifiable and likely to contribute effectively to the goal of long term human development. 


\section{References}

Alderman, Harold, Jere R. Behrman, Victor Lavy, and Rekha Menon (2001). "Child health and school enrollment," Journal of Human Resources, 36(1), 185-205.

Alderman, Harold, John Hoddinott, and Bill Kinsey. (2006). 'Long term consequences of early childhood malnutrition," Oxford Economic Papers, 58(3), 450-474.

Alderman, Harold, Hans Hoogeveen, and Mariacristina Rossi. (2009). “Preschool Nutrition and Subsequent Schooling Attainment: Longitudinal Evidence from Tanzania," Economic Development and Cultural Change, 57(2), 239-260.

Almond, Douglas, (2006). "Is the 1918 Influenza Pandemic Over? Long Term Effects of In Utero Influenza Exposure in the Post-1940 U.S. Population," Journal of Political Economy, 114(4), 672-712.

ASEAN Coffee (2008).

http://www.coffeeasean.org/details.asp?Object=7\&news_ID=191273691.

Barker, D.J.P., (1998). Mothers, Babies, and Health in Later Life, Churchill, Livingston, Edinburgh.

Bozzoli , Carlos, Angus Deaton, and Climent Quintana-Domeque. (2009). "Adult height and childhood disease," Demography, 46(4), 647-669.

Deaton, Angus. (2010). "Instruments, Randomization, and Learning about Development," Journal of Economic Literature, 48(2), 424-452.

Dollar, David and Jennie Litvack. (1998). "Macroeconomic Reforms and Poverty Reduction in Vietnam," In: Dollar, David, Paul Glewwe and Jennie Litvack (eds.) Household Welfare and Vietnam's Transition, The World Bank, Washington, DC, 1-28.

Glewwe, Paul. (2004). “An Investigation of the Determinants of School Progress and Academic Achievement in Vietnam," Economic Growth, Poverty, and Household Welfare in Vietnam, chapter 13, 467-501. The World Bank's Regional and Sectoral Studies No. 29086.

Glewwe, Paul, and Hanan G. Jacoby. (1995). “An economic analysis of delayed primary school enrollment in a low income country: The role of early childhood nutrition," Review of Economics and Statistics, 77(1), 156-169.

Glewwe, Paul, Hanan G. Jacoby, and Elizabeth M. King. (2001). "Early childhood nutrition and academic achievement: A longitudinal analysis," Journal of Public Economics, 81(3), 345-368. 
Glewwe, Paul, and Edward A. Miguel. (2008). "'The Impact of Child Health and Nutrition on Education in Less Developed Countries,". In: Schultz, T. Paul, and John Strauss, (Eds.), Handbook of Development Economics, vol. 4, Chapter 10, Elsevier/North-Holland, Amsterdam.

Hoddinott, John, and Bill Kinsey. (2001). "Child growth in the time of drought," Oxford Bulletin of Economics and Statistics, 63(4), 409-436.

Legates, David R., and Cort J. Willmott. (1990). “Mean Seasonal and Spatial Variability in Gauge-Corrected, Global Precipitation," International Journal of Climatology, 10(2), 111-127.

Maccini, Sharon, and Dean Yang. (2009). 'Under the Weather: Health, Schooling, and Economic Consequences of Early-Life Rainfall," The American Economic Review, 99(3), 1006-1026.

Ravallion, Martin and Dominique Van de Walle, (2008). Land in Transition: reform in rural Vietnam, The World Bank, Washington, DC.

Strauss, John, and Duncan Thomas. (1998). “'Health, Nutrition, and Economic Development," Journal of Economic Literature, 36(2), 766-817.

Strauss, John and Duncan Thomas. (2008). "Health over the Life Course,". In: Schultz, T. Paul, and John Strauss, (Eds.), Handbook of Development Economics, vol. 4, Chapter 8, Elsevier/North-Holland, Amsterdam.

Sumernet, "Challenges to Sustainable Development in the Mekong Delta: Regional and National Policy Issues and Research Needs,"

http://www.sumernet.org/index.php?option=com_k2\&view=item\&id=8:challenge, accessed June 29, 2011.

The World Bank. (1996). “Annex 5.1. Rates of Return for Wage Workers Based on Estimations of the Human Capital Earnings Function". In: Vietnam Education Financing Sector Study. Report No. 15925-VN, Human Resources Operations Division, Country Department, East Asia and Pacific Region.

Trenberth, Kevin E., (1997). “The Definition of El Niño,” Bulletin of the American Meteorological Society, 78(12), 2771-2777.

United Nations (2000). “Lessons from the 16-Country UNEP Study". In: Reducing the Impact of Environmental Emergencies through Early Warning and Preparedness: The Case of the 1997-98 El Niño - A UNEP/NCAR/UNU/WMO/ISDR Assessment.

Wiens, Thomas B. (1998). "Agriculture and Rural Poverty in Vietnam". In: Dollar, David, Paul Glewwe and Jennie Litvack (eds.) Household Welfare and Vietnam's Transition, The World Bank, Washington, DC, 61-98. 
Zimmermann, Laura, (2011). "Remember When It Rained: Gender Discrimination in Elementary School Enrollment in India," working paper, University of Michigan. 